\title{
Do SMEs Need Business Incubation for Productive Capacity Levels? - A Case Study
}

\author{
Dinesh Khanduja* Sahib Sartaj Singh**
}

\begin{abstract}
In India, among the start ups many new ventures fail and for the few that survive and grow, there are always numerous problems. In order to make these surviving units productive and cost effective in today's competitive environment, 'Business Incubation' is emerging as one of the most innovative instruments to support small enterprises. In this direction in India, following on the world pattern, several initiatives have been taken over the last decade to encourage the concept of business incubation. Besides profiling the existing 'Business Incubators' in India, the paper dwells upon a case study for exploring the relevance of business incubation for enhancing the productive capacity.
\end{abstract}

Keywords-Business Incubation, Technology Business Incubator (TBI), Rural Business Hub (RBH), Entrepreneurship, Business Development Services (BDS), Technology Management

\section{Introduction}

In present dynamically changing society there is an urgent need to create an environment of entrepreneurship to effectively counter many socioeconomic ills like higher population growth, declining GDP, growing inflation, illiteracy and unemployment.. Entrepreneurship is a dynamic process of vision, change and creation (Kuratko and Hodgetts, 2004). The characteristics of seeking opportunities, taking risks beyond security, and having the tenacity to push an idea through to reality combine into a special perspective that permeates entrepreneurs.

Dinesh Khanduja

Professor, Mechanical Engineering Department

National Institue of Technology, Kurukshetra (Haryana), India

Sahib Sartaj Singh

Department of Mechanical Engineering,

Punjabi University, Pastiala (Punjab), India
Entrepreneurship has always been the best form of gainful self-employment and so has a great future role for the economic development. With 'Incubated Business' getting focused to attract public and private sector support, strategic partnerships and alliances have become compelling for the business enterprises.. A climate for stimulating innovation and facilitating meaningful technology transfer can be created through change in cultural attitudes and by a systematic approach to build linkages between education, research, enterprises, finance and the government. To foster entrepreneurship and development; education, training and research have geared together to relevance, competence and excellence by establishing 'Technology Business Incubators' (TBIs) all over the nation.

\section{Business Incubation}

The importance of business incubation is twofold. Firstly, it favors the setting up of new companies and secondly, it provides them appropriate business support needed to increase the chances of their survival and growth. A business incubator is a tool to facilitate enterprise creation and development (Alistair, 2003). Nurturing of technology intensive small and medium firms through incubators has been recognized as one of the main devices of Korean economic policy (Kark, 2003). On similar lines, 'Third Italy' also owes rapid growth to the concept of industrial districts used to capture the success of agglomerations of small firms and this Italian experience has given impetus to research on industrial districts (UNIDO Report, 2005). China too has made efforts to accelerate the birth and growth of incubators, with the aim of rapidly catching up with developed countries of Europe (Chen Jin et al, 2003). These incubators work on four different models:

$>$ Local Economic Development Incubators;

$>$ Academic and Scientific Incubators;

$>$ Corporate Incubators; and

$>$ Private Investors' Incubators.

All these business incubators work on certain basic principles like: 
Proc. of the Intl. Conf. on Advances in Civil, Structural and Mechanical Engineering - ACSM 2015.

Copyright $\odot$ Institute of Research Engineers and Doctors, USA .All rights reserved.

ISBN: 978-1-63248-039-2 doi: 10.15224/ 978-1-63248-039-2-92

Focus on Wealth Creation

Encourage Entrepreneurship

$>$ Provide Value to Tenants and Stakeholders

$>$ Manage the Incubator more like a business.

\section{Promoting Business with TBIs in India}

The entrepreneurial spirit is universal, judging by the enormous growth of interest in entrepreneurship around the world in the past few years (Peng, 2001). NSTEDB (National Science and Technology Entrepreneurship Development Board), since its inception in 1982 in India, has launched several programs/schemes for entrepreneurship development and in 2000 , guided by the global experience, it initiated a scheme for establishment of TBIs to promote start-up companies in the high-tech areas (NSTEDB Report-a, 2005). These incubators have been planned to nurture new ventures by providing specialized guidance, critical support services, innovative financing and networking support within a well-equipped workspace. Presently around seventy incubators have been providing various services like market surveys, marketing assistance and business planning, Information on product ideas etc.

\section{Profiling Business Incubators in India}

An attempt has been made to classify the existing TBIs in India on the basis of working models, thrust areas, age, objectives, occupancy rates etc. Figure 1 to figure 3 depict distribution of various types of incubators in the country

. Figure 1: Distribution on Basis of Working Models

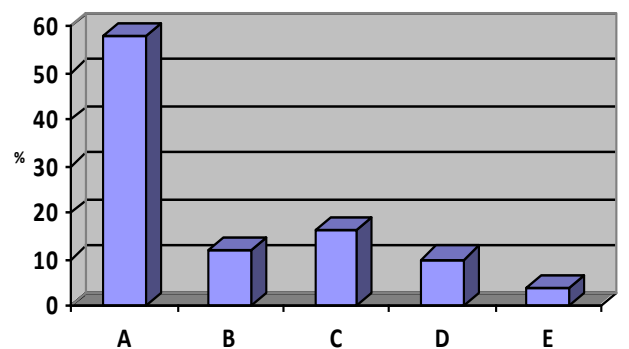

\begin{tabular}{|l|l|l|}
\hline A & Academic TBIs & $58 \%$ \\
\hline B & Corporate Incubators & $12 \%$ \\
\hline C & Local Area Incubators & $16 \%$ \\
\hline D & Private Incubators & $10 \%$ \\
\hline E & Virtual Incubators & $04 \%$ \\
\hline
\end{tabular}

Figure 2: Distribution on Basis of Thrust Areas

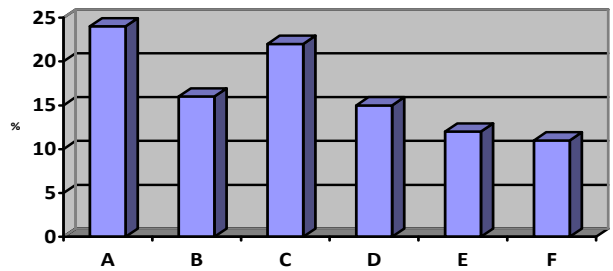

\begin{tabular}{|c|l|l|}
\hline A & Biotech/Chemical Sciences & $24 \%$ \\
\hline B & Agriculture/Allied Fields & $16 \%$ \\
\hline C & I C Technology & $22 \%$ \\
\hline D & Advanced Technologies & $15 \%$ \\
\hline E & Services & $12 \%$ \\
\hline F & Others & $11 \%$ \\
\hline
\end{tabular}

Figure 3: Distribution on Basis of Occupancy Rate

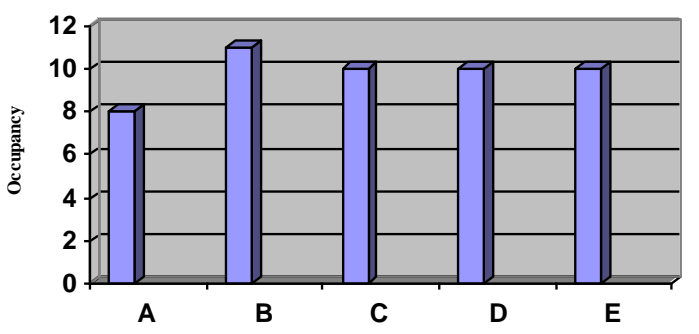

\begin{tabular}{|ll|l|}
\hline A & Biotech/Chemical Sciences & $08 \%$ \\
\hline B & Agriculture/Allied Fields & $11 \%$ \\
\hline C & I C Technology & $10 \%$ \\
\hline D & Advanced Technologies & $10 \%$ \\
\hline E & Services & $09 \%$ \\
\hline
\end{tabular}

All these profiles and characteristics indicate some definite patterns on which the TBIs are evolving in India. Major observations from this part are:

(a) Majority of the TBIs are attached to academic and R\&D institutes and are supported by DST .

(b) Almost 50\% incubators are supported in the thrust areas of ICT and biotechnology /chemical sciences. Incubators in the areas of advanced technologies, management services and agro-allied fields are too few in numbers when compared to economic development and vastness of the nations.

(c) Western and southern India alone account for $75 \%$ of TBIs.

(d) Occupancy rate in the incubators is far less when compared with data of US, China etc. The growth rate of incubators is slow but consistently increasing since their inception in 2000

Strategic planning needs to be done on this issue as low occupancy leads to low utilization of resources and infrastructure and developing nation like India cannot afford it. 
Proc. of the Intl. Conf. on Advances in Civil, Structural and Mechanical Engineering - ACSM 2015.

Copyright $\odot$ Institute of Research Engineers and Doctors, USA .All rights reserved.

ISBN: 978-1-63248-039-2 doi: 10.15224/ 978-1-63248-039-2-92

\section{Are TBIs Relevant for SMEs in India?: A Case Study}

The paper also explores the relevance of TBIs in India by analyzing the needs of SMEs for various possible business development supports in the present day environment and the availability of sources satisfying these needs. So in the present study; relevance, necessity and availability have been statistically analyzed and related as:

$\mathrm{RI}=\mathrm{NI}-\mathrm{AI}$, where RI = Relevance Index, NI = Necessity Index, AI = Availability Index

50 enterprises were selected in Punjab in different thrust areas and the objectives of this survey were to find the relevance of different BDSs to be provided by TBIs in India. For survey, a questionnaire on BDSs by an incubator was prepared to analyse the gap between 'necessity level' and 'availability level' of different services which was used to compute the 'relevance level' for TBIs in different thrust areas. Thirty two responses were obtained and descriptive statistics like mean and standard deviation were calculated for each thrust area in different service groups. Calculation of $\bar{X}$ and $S$ helped in further calculations for hypothesis testing. Null Hypothesis $\mathrm{H}_{1}$ was set which states that there is no significant difference between two samples means $\left(\overline{\boldsymbol{X}}_{1}, \overline{\boldsymbol{X}}_{2}\right)$ of two independent thrust areas on relevance. This hypothesis was tested by t-test method. The tdistribution is used when sample size is less than 30 . For hypothesis $\mathrm{H}_{1}, \mathrm{t}$-test was performed at $5 \%$ level of significance except in closely lying results either at $2 \%$ or $10 \%$ level of significance. When calculated $t$ is $<$ tabulated $\mathrm{t}$, then $(+) \mathrm{H}_{1}$ : Hypothes is accepted at $5 \%$ level or level mentioned against figure. When calculated $\mathrm{t}$ is $>$ tabulated $\mathrm{t}$, then $(-) \mathrm{H}_{1}$ : Hypothesis is rejected at 5\% level or level mentioned against figure.

Table 1 'Relevance Index' for TBIs in Different Thrust Areas

\begin{tabular}{|c|c|c|c|c|c|c|}
\hline $\begin{array}{c}\text { Thrust } \\
\text { area }\end{array}$ & $\begin{array}{c}\text { G- } \\
\text { I }\end{array}$ & $\begin{array}{c}\text { G- } \\
\text { II }\end{array}$ & $\begin{array}{c}\text { G- } \\
\text { III }\end{array}$ & $\begin{array}{c}\text { G- } \\
\text { IV }\end{array}$ & $\begin{array}{c}\text { G- } \\
\text { V }\end{array}$ & RI(\%) \\
\hline A & .53 & .62 & .74 & .62 & .76 & $65 \%$ \\
\hline B & .62 & .60 & .65 & .56 & .70 & $63 \%$ \\
\hline C & .57 & .64 & .58 & .39 & .51 & $54 \%$ \\
\hline D & .42 & .62 & .54 & .52 & .35 & $49 \%$ \\
\hline E & .22 & .40 & .41 & .52 & .49 & $41 \%$ \\
\hline $\begin{array}{l}\text { Average } \\
\text { score }\end{array}$ & .47 & .57 & .58 & .52 & .56 & $\mathbf{5 4 \%}$ \\
\hline
\end{tabular}

Table 1 gives the projection of 'Relevance Index' for TBIs in different thrust areas. Further these findings were statistically validated with t-test. Table 4 gives a summary of acceptability of hypothesis $\mathrm{H}_{1}$ at various levels for various types of services provided by the TBIs at various clusters.

Table 2: Acceptability of Null Hypothesis $\mathrm{H}_{1}$ at Various Levels

\begin{tabular}{|l|c|c|c|c|}
\hline Levels $\rightarrow$ & $5 \%$ & $2 \%$ & $10 \%$ & Not Accepted \\
\hline Physical Facilities & 1 & - & - & 9 \\
\hline $\begin{array}{l}\text { Technical Advisory } \\
\text { Support }\end{array}$ & 1 & 2 & 4 & 3 \\
\hline $\begin{array}{l}\text { Business } \\
\text { Management }\end{array}$ & 1 & 1 & 3 & 5 \\
\hline Financial Services & 2 & 1 & 1 & 6 \\
\hline Networking support & - & 1 & 1 & 8 \\
\hline
\end{tabular}

'Relevance index' for different TBIs over major thrust areas can be presumed as: ICT sector: $65 \%$, Bio-tech sector: $63 \%$, Instrumentation sector: $54 \%$, Agriculture sector: $49 \%$ and Garments-Fashion Technology sector: $41 \%$. Among various business development supports provided by TBIs, 'Business Management Support' has maximum relevance 58\% and 'Physical Facilities' has minimum relevance 47 $\%$. Relevance Scores for other services like 'Technical Advisory Support has 57\%, 'Financial Support' and 'Networking Support' are 57\%, 52\% and $56 \%$ respectively. But this amount of relevance shall vary from place to place, depending upon the availability of the BDSs. A good number of combinations of thrust areas (31 out of 50), over all five business supports, have rejected $\mathrm{H}_{1}$ (refer table 2 ) which shows that there is a strong absence of any similarity on patterns of relevance between two thrust areas also.

\section{Conclusions}

'Technology Business Incubators' are excellent forums for incubation of small enterprises, which is so essential for economic empowerment of India in today's highly volatile market. These forums also help in exploring some key issues like optimal utilization of natural endowments and downsizing of technology directly to SMEs. The growth of these incubators has picked up in the recent past but their impact is still not being felt in Indian environment. Expectation minus perception on BDSs is comparatively high in ICT and Biotech thrust areas as compared to other sectors, so more TBIs are needed in these areas. At the incubator premises, the need for technical advisory, business development and networking support is much more as compared to the availability of physical facilities and financial 
Proc. of the Intl. Conf. on Advances in Civil, Structural and Mechanical Engineering - ACSM 2015.

Copyright $\odot$ Institute of Research Engineers and Doctors, USA .All rights reserved.

ISBN: 978-1-63248-039-2 doi: 10.15224/ 978-1-63248-039-2-92

support. Survey findings on need for business incubators in some thrust areas in Punjab point towards high relevance of the incubators and same trend is expected to exist in rest of the country. So if these incubators provide a right mix of services at reasonable cost, then these can surely contribute towards effective enhancement in productive capacity.

\section{References}

1) Alistair Nolan (2003) 'Public Policy on Business Incubators: An OECD Perspective', Journal of Entrepreneurship and Innovation Management, Vol.3, pp. 22-30.

2) Chaganti, R. and Greene, P.G. (2002) 'Who Are Ethnic Entrepreneurs? A Study of Entrepreneurs' Ethnic Involvement and Business Characteristics'. Journal of Small Business Management, Vol. 40(2), pp. 126-143.

3) Chen Jin, Yin Jainseng and Zhu Mio (2003) 'Business Incubators in China', Journal of Entrepreneurship and Innovation Management, Vol. 3, pp. 67-77.

4) Greene, P.G., Hart, M.M., Brush, C.G. and Carter, N.M. (2003) 'Women Entrepreneurs: Moving Front and Center: An Overview of Research and Theory', Coleman Series.

5) Gundry, L.K. and Welsch, H.P. (2001) 'The Ambitious Entrepreneur: High Growth Strategies of Women Enterprises', Journal of Business Venturing, Vol. 16(5), pp. 453-470.

6) INDIACO (2005) http://www.indiaco.com/.

7) Kark Bum Lee (2003) 'The Evolutionary Process of Venture Incubation in Korea', Journal of Entrepreneurship and Innovation Management, Vol. 3, pp. 78-86.

8) Kent, C.A. (1990) 'Entrepreneurship Education at the Collegiate Level: A Synopsis and Evaluation', Entrepreneurship Education, New York: Quorum Books.

9) Kuratko, D.F. and Hodgetts, R.M. (2004) Entrepreneurship: Theory, Process and Practice, Mason, $\mathrm{OH}$; Southwestern Publishers.

10) Lalkaka Rustam (2003) 'Business Incubators in Developing Countries; Performance', International. Journal of Entrepreneurship and Innovation Management, Vol. 3, pp. 31-58.

11) NSTEDB Report-a http://dst.gov.in/scprog/nstedb.htm\#intro

12) NSTEDB Report-b (2005), http://dst.gov.in/scprog/achiev_nstedb.htm

13) Peng, M.W. (2001) 'How Entrepreneurs Create Wealth in Transition Economies', Journal of Academy of Management Executive, Vol. 15(1), pp. $95-110$.
14) Third Italy (2005), Terza Italia, http://eurofound.eu.int/legal/copyright.htm/

15) UNIDO Report (2005), The UNIDO Clusters/Network Development Programme: 
Proc. of the Intl. Conf. on Advances in Civil, Structural and Mechanical Engineering - ACSM 2015.

Copyright $\odot$ Institute of Research Engineers and Doctors, USA .All rights reserved.

ISBN: 978-1-63248-039-2 doi: 10.15224/ 978-1-63248-039-2-92

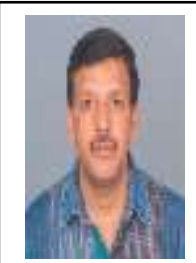

Dinesh has a teaching experience

of 26 years; areas of interest

include Six Sigma, Lean \& agile

manufacturing and

entrepreneurship.

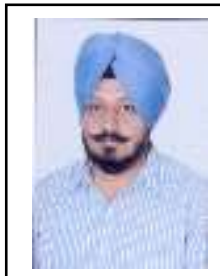

Sahib has a long teaching and administrative experience at different engineering colleges. His areas of interest are Business Incubation and Total Quality Management. 